\title{
HUBUNGAN POLA MAKAN, KONDISI PSIKOLOGIS, DAN AKTIVITAS FISIK DENGAN DIABETES MELLITUS PADA LANSIA DI PUSKESMAS KUMAI
}

\author{
${ }^{1}$ Dwi Suprapti \\ ${ }^{1}$ STIKES Borneo Cendekia Medika Pangkalan Bun \\ ${ }^{1}$ Email : dwi.suprapti99@gmail.com
}

\begin{abstract}
ABSTRAK
Lanjut usia dapat dikatakan sebagai tahap akhir perkembangan pada daur kehidupan seorang manusia. Diabetes mellitus (DM) adalah salah satu jenis penyakit degeneratif yang mengalami peningkatan setiap tahun di seluruh dunia. Kejadian DM di Indonesia mengalami peningkatan, pada tahun 2007 sebesar $(5,7 \%)$ menjadi $(6,9 \%)$ pada tahun 2013. DM pada lansia di Indonesia merupakan masalah yang penting untuk dilakukan tindakan pencegahan dan pengendalian DM. Tujuan penelitian ini untuk menganalisis faktor hubungan pola makan, kondisi psikologis, dan aktivitas fisik dengan DM pada lansia terhadap risiko kejadian DM lansia. Jenis penelitian ini adalah kuantitatif dengan pendekatan cross sectional. Sampel dipilih secara purpossive berdasarkan kriteria usia 60-90 tahun, tidak memiliki komplikasi penyakit lain, masih mampu berkomunikasi dengan baik, bersedia menjadi responden, yakni sejumlah 165 subjek. Teknik pengumpulan data menggunakan angket atau wawancara. Analisis menggunakan univariat, bivariat menggunakan uji Chi-square dan multivariat menggunakan Regresi logistic sederhana dengan menggunakan program komputer. Distribusi frekuensi berdasarkan kejadian DM sebesar $(53,3 \%)$, pola makan sering $>3 x$ /hari (54\%), stress $(54,5 \%)$, aktivitas fisik ringan $(61,2 \%)$, umur lanjur $(52,1 \%)$, jenis kelamin perempuan $(67,3 \%)$, suku Jawa $(71,5 \%)$ dan pendidikan rendah $(73 \%)$. Hasil penelitian didapatkan ada hubungan antara kondisi psikologis, jenis kelamin, suku dan pendidikan dengan status DM. Pola makan menjadi variabel yang dominan dengan kejadian DM pada lansia $(p-$ value 0.006 , OR 2.950). Artinya lansia yang memiliki pola makan sering $>3 x /$ hari memiliki peluang sebanyak 3 kali lebih tinggi untuk terkena DM dibandingkan yang memiliki pola makan jarang $<3 x /$ hari. Sehingga lansia diharapkan melakukan olahraga ringan, mengikuti promosi kesehatan mengenai DM yang diberikan oleh tenaga kesehatan, serta berobat rutin bagi lansia yang sudah terdiagnosa DM guna mengurangi risiko terkena DM.
\end{abstract}

Kata Kunci: Pola makan, aktivitas fisik, stress, lansia.

RELATIONSHIP OF EATING PATTERNS, PSYCHOLOGICAL CONDITIONS, AND PHYSICAL ACTIVITIES WITH MELLITUS DIABETES IN ELDERLY IN KUMAI PUSKESMAS

\section{ABSTRACT}

Old age can be said to be the final stage of development in a human's life cycle. Diabetes mellitus (DM) is a type of degenerative disease that has increased every year throughout the world. The incidence of DM in Indonesia has increased, in 2007 by (5.7\%) to (6.9\%) in 2013. DM in the elderly in Indonesia is an important issue for 
DM prevention and control. The purpose of this study was to analyze factors related to diet, psychological conditions, and physical activity with DM in the elderly to the risk of the incidence of DM in the elderly. This type of research is quantitative with a cross sectional approach. The sample was selected purposively based on the criteria of age 60-90 years, had no complications of other diseases, was still able to communicate well, was willing to be a respondent, ie a number of 165 subjects. Data collection techniques using questionnaires or interviews. Analysis using univariate, bivariate using Chi-square test and multivariate using simple logistic regression using a computer program. Frequency distribution based on DM incidence (53.3\%), frequent eating patterns > 3x / day (54\%), stress (54.5\%), mild physical activity $(61.2 \%)$, longevity (52.1\%), female gender (67.3\%), Javanese (71.5\%) and low education (73\%). The results found there is a relationship between psychological conditions, gender, ethnicity and education with DM status. Diet is the dominant variable with the incidence of DM in the elderly (p-value 0.006, OR 2950). This means that elderly people who have a diet often $>3 x /$ day have a 3 times higher chance of developing DM than those who have a rarely eat pattern $<3 x /$ day. So that the elderly are expected to do moderate exercise, take part in health promotion regarding DM given by health workers, as well as routine medical treatment for the elderly who have been diagnosed with DM in order to reduce the risk of DM.

Keywords: Eating patterns, physical activity, stress, elderly

\section{PENDAHULUAN}

Diabetes mellitus merupakan kondisi kronis yang ditandai dengan peningkatan konsentrasi glukosa darah disertai munculnya gejala utama yang khas, yakni urine yang berasa manis dalam jumlah yang besar. Diabetes mellitus adalah salah satu jenis penyakit degeneratif yang mengalami peningkatan setiap tahun di negara-negara seluruh dunia. Diabetes mellitus yang umum dikenal sebagai kencing manis adalah penyakit yang ditandai dengan hiperglikemia (peningkatan kadar gula darah) yang terusmenerus dan bervariasi, terutama setelah makan (Bilous, 2014).

Diabetes melllitus masuk sebagai salah satu penyakit yang sering dijumpai pada usia lanjut. Hampir $50 \%$ pasien diabetes berusia 65 tahun ke atas. Menurut International of Diabetic Federation (IDF, 2015) tingkat prevalensi global penderita DM pada tahun 2014 sebesar 8,3\% dari keseluruhan penduduk di dunia dan mengalami peningkatan pada tahun
2015 menjadi 387 juta kasus. Data dari World Health Organization (WHO), sekitar 347 juta orang di seluruh dunia menderita diabetes, dan diperkirakan bahwa kematian akibat diabetes akan meningkat dua pertiga kali antara tahun 2008 dan 2030. Beban diabetes meningkat secara global, khusunya di negara berkembang (WHO, 2012).

Pada tahun 2011, Indonesia menempati urutan ke-10 jumlah penderita DM terbanyak di dunia dengan jumlah 7,3 juta orang dan jika hal ini berlanjut diperkirakan pada tahun 2030 penderita DM dapat mencapai 11,8 juta orang. Angka kejadian DM menurut data Riskesdas (2013) terjadi peningkatan dari 5,7\% di tahun 2007 meningkat menjadi 6,9 $\%$ di tahun 2013 dari keseluruhan penduduk sebanyak 250 juta jiwa.

Prevalensi data penderita DM di Provinsi Jawa Tengah pada tahun 2014 mengalami peningkatan dari 14,96\% menjadi $16,69 \%$ pada tahun 2015. Peningkatan prevalensi 
data penderita DM di atas salah yang mencapai 152.075 kasus. Jumlah penderita DM tertinggi 5.919 jiwa di Kota Semarang (Profil Kesehatan Jawa Tengah, 2011). Data Depkes RI (2012) menunjukkan ratarata kasus penderita diabetes mellitus di Jawa Tengah sebanyak 4.216 kasus.

Diabetes mellitus menjadi masalah kesehatan bagi masyarakat utama karena komplikasinya bersifat jangka pendek dan jangka panjang (Bilous, 2014). Diabetes mellitus di picu oleh faktor-faktor seperti makan yang berlebihan, kurang gerak, kehamilan, kekurangan produksi hormone insulin, dan penyakit hormon yang kerjanya berlawanan dengan insulin (Soegono, 2004). Menurut Suyono (2007), penyakit diabetes melitus tipe II merupakan penyakit degeneratif yang sangat terkait pola makan. Pola makan merupakan gambaran mengenai macam macam, jumlah dan komposisi bahan makanan yang dimakan tiap hari oleh seseorang. Gaya hidup perkotaan dengan pola diit yang tinggi lemak, garam, dan gula secara berlebihan mengakibatkan berbagai penyakit termasuk diabetes mellitus. Berdasarkan penelitian yang dilakukan oleh Zurianti S. Manto (2015), didapatkan bahwa ada hubungan antara pola makan dan olahraga dengan kejadian Diabetes Mellitus Tipe 2 di Puskesmas Tilamata Kab. Baelemo.

Selain pola makan, stress juga dapat mempengaruhi kejadian diabetes mellitus pada seseorang. Stress merupakan keadaan tertekan, baik secara fisik maupun psikologis. Keadaan yang membuat tertekan ini karena adanya kebutuhan dan dorongan yang tidak sesuai dengan kenyataan yang diharapkan, serta respon masing-masing individu yang berbeda (Chaplin,2000). Tahapan sebelum seseorang mengalami stres, ia akan mengalami frustasi terlebih dahulu karena sesuatu yang menghambat tercapainya tujuan hidup itulah yang dinamakan frustasi. Frustasi yang terus menerus dan orang yang bersangkutan tidak mampu mengatasinya maka keadaan tersebut dinamakan stres.
Stress dan diabetes mellitus memiliki hubungan yang sangat erat terutama pada penduduk perkotaan. Tekanan kehidupan dan gaya hidup tidak sehat sangat berpengaruh, ditambah dengan kemajuan teknologi yang semakin pesat dan berbagai penyakit yang sedang di derita menyebabkan penurunan kondisi seseorang sehingga memicu terjadinya stress. Vranic et al. (2000) menyebutkan stress pada penderita diabetes mellitus dapat mengakibatkan gangguan pada pengontrolan kadar gula darah. Dua faktor risiko yang bisa mengembangkan diabetes adalah kelebihan berat badan dan kurangnya aktivitas fisik.

Latihan fisik pada penderita DM memiliki peranan yang sangat penting dalam mengendalikan kadar gula dalam darah, dimana saat melakukan latihan fisik terjadi peningkatan pemakaian glukosa oleh otot yang aktif sehingga secara langsung dapat menyebabkan penurunan glukosa darah. Selain itu dengan latihan fisik dapat menurunkan berat badan, meningkatkan fungsi kardiovaskuler dan respirasi, menurunkan LDL dan meningkatkan HDL sehingga mencegah penyakit jantung koroner apabila latihan fisik ini dilakukan secara benar dan teratur (WHO,2001). Adapun cara pencegahan komplikasi pada penderita DM yaitu dengan cara melakukan kontrol kadar gula darah, periksa rutin gula darah, konsumsi obat hipoglikemi, latihan fisik ringan dan patuh dalam diit rendah kalori (Arisman, 2011).

Umur secara kronologis hanya merupakan suatu determinan dari perubahan yang berhubungan dengan penerapan terapi obat secara tepat pada orang lanjut usia. Terjadi perubahan penting pada respon terhadap beberapa obat dengan bertambahnya umur pada sejumlah besar individu (Katzung, 2004). Pencegahan pada diabetes mellitus terdiri dari tiga tahap, yaitu pencegahan primer, pencegahan sekunder, dan pencegahan tersier (WHO, 1994).

Lanjut usia adalah suatu proses alami yang akan terjadi dan tidak dapat dihindari 
(Azwar, 2006). Menurut UU No. 4 tahun 1995 lansia adalah seseorang yang telah mencapai usia 55 tahun, tidak berdaya mencari nafkah sendiri untuk keperluan hidupnya sehari-hari dan menerima nafkah dari orang lain maupun dari keluarga (Wahyudi, 2000).

Berdasarkan pengertian lanjut usia secara umum, seseorang dikatakan lanjut usia apabila mereka berusia 65 tahun keatas (Effendi dan Makhfudli, 2009). Usia lanjut dapat dikatakan sebagai tahap akhir perkembangan pada daur kehidupan seorang manusia. Sedangkan menurut Pasal 1 ayat (2), (3), dan

(4) UU No. 13 tahun 1998 tentang kesehatan dikatakan bahwa usia lanjut adalah seseorang yang telah mencapai usia 60 tahun ke atas (Maryam dkk, 2008).

Hasil survei dari Dinas Kesehatan Kabupaten Koatawaringin Barat tahun 2015 terdapat jumlah penderita Diabetes Mellitus usia 50-70 tahun sejumlah 2.147 lansia Diabetes Mellitus, total jumlah lansia di puskesmas kumai sejumlah 3.461 lansia sehat maupun yang sakit, sedangkan lansia yang menderita penyakit Diabetes Mellitus di wilayah kerja Puskesmas kumai sejumlah 214 lansia. Berdasarkan survei awal pada tanggal 28 September 2017 di Puskesmas kumai terdapat 6 dari 10 pasien lansia positif diabetes mellitus, dan selanjutnya perlu diteliti faktor-faktor yang berhubungan dengan kejadian diabetes mellitus pada lansia.

\section{METODE PENELITIAN}

Penelitian ini merupakan jenis penelitian kuantitatif dengan menggunakan desain cross sectional, yaitu penulusuran sesaat, artinya pengukuran variabel-variabelnya dilakukan hanya satu kali. Untuk memperoleh informasi tentang variabel dependen dan variabel independen maka pengukurannya dilakukan bersama-sama pada saat penelitian dengan menggunakan kuesioner (Sugiyono,2014)
Penelitian ini telah dilakukan pada tanggal 06 Desember - 01 Januari 2017 di Wilayah kerja Puskesmas Kumai.

Populasi dalam penelitian ini adalah seluruh lansia yang di Puskesmas Kedungmundu Semarang yaitu berjumlah 3.461 kasus. Berdasarkan perhitungan sampel yang menjadi responden dalam penelitian ini sebanyak 165 orang, sampel diambil berdasarkan kriteria inkulsi dan eksklusi. Teknik pengambilan sampel dalam penelitian ini menggunakan teknik Purposive Sampling, yaitu pengambilan sampel yang didasarkan pada suatu pertimbangan tertentu yang dibuat oleh peneliti, berdasarkan ciri atau sifat-sifat populasi yang sudah diketahui sebelumnya (Sugiyono, 2013).

Adapun kriteria inklusi dan eksklusi dari sampel penelitian adalah sebagai berikut :

a. Kriteria Inklusi

Kriteria inklusi dalam penelitian ini adalah : lansia berusia 60-90 tahun, lansia yang tidak memiliki komplikasi penyakit lain, masih mampu berkomunikasi dengan baik, bersedia menjadi responden, sedang berada ditempat pada saat pengambilan data.

b. Kriteria Eklusi

Kriteria eklusi dalam penelitian ini adalah semua lansia yang memenuhi syarat namun tidak dapat hadir pada saat pengambilan data.

\section{Teknik dan Instrumen Pengumpulan Data}

1) Instrumen Penelitian

a. Kuesioner A : data karakteristik responden yang terdiri atas: kode responden, umur, jenis kelamin, suku, status pekerjaan dan pendidikan.

b. Kuesioner B : Terdiri dari kuesioner pola makan, stress dan kuesioner aktivitas fisik. Data pola makan diperoleh melalui kuesioner FFQ (Food Frequency Quesionaire), penghitungan skor nya menggunakan skala likert dan di kategorikan menjadi dua 
kategori pola makan over dan pola makan kurang.

Data stres diperoleh dengan menggunakan kuesioner DASS (Depression Anxiety Stress Scale) untuk memeriksa pengaruh kesehatan terhadap stres yang terjadi dalam kehidupan sehari-hari, semua penilaian diakumulasikan kemudian disesuaikan dengan tingkat stres (normal, ringan, sedang, berat, dan sangat berat). Data aktivitas fisik diperoleh dengan menggunakan kuesioner dari IPAQ (International Physical Activity Questionnaire) semua penelitian di akumulasikan kemudian disesuaikan dengan aktivitas fisik dan dikategorikan menjadi aktivitas ringan, aktivitas sedang dan aktivitas berat.

\section{Metode Pengumpulan Data}

a) Mengurus surat izin penelitian Dinkes Provinsi Kalimantan Tengah.

b) Mengurus izin penelitian ditempat penelitian, yaitu kepada Kepala Puskesmas Kumai dan menyampaikan maksud tujuan penelitian.

c) Dalam penelitian ini, peneliti dibantu oleh 3 orang rekan nya guna untuk mempermudah proses pengumpulan data yang dilakukan pada waktu yang telah ditentukan.

d) Penelitian dimulai dari penetapan responden ynag menjadi sampel dalam penelitian ini yaitu dengan cara mengundang para lansia pada tempat yang sudah disiapkan.

e) Setelah semua responden hadir ditempat yang sudah disiapkan, diberikan penjelasan tentang prosedur pelaksanaan penelitian yang akan dilakukan.

f) Tahap selanjutnya dilakukan pengukuran tensi darah responden dan pengambilan darah pada jari responden guna mengukur kadar gula darah responden satu persatu menggunakan alat cek gula darah Easy Touch yang sebelumnya di sterilkan menggunakan kapas alkohol.

g) Lalu untuk mengetahui pola makan lansia dengan membagikan kuesioner FFQ (Food Frequency Quetionnaire) dilakukan oleh peneliti dengan waktu \pm 20 menit. Kemudian pengambilan data untuk mengetahui tingkat stres lansia dengan membagikan kuesioner DASS (Depression Anxiety Stress Scale) dilakukan oleh peneliti dengan waktu \pm 20 menit.

h) Selanjutnya dilakukan pengambilan data untuk mengetahui aktivitas fisik lansia dengan membagikan kuesioner IPAQ (International Physical Activity) dilakukan oleh peneliti dengan waktu

\pm 20 menit. Tahap selanjutnya responden diberikan kesempatan untuk bertanya tentang materi ynag telah disampaikan yang belum dipahami.

i) Tahap terakhir adalah melakukan editing, coding, scoring, dan tabulating, dari data yang telah didapat.

Sumber data dalam penelitian adalah subjek darimana data diperoleh. Data yang dikumpulkan dalam penelitian ini adalah:

a) Data Primer adalah data yang didapat secara langsung dari penelitian atau sampel, meliputi: Data identitas responden, dan data yang diperoleh dari kuesioner yang digunakan untuk mengukur pola makan, stres, dan aktivitas fisik.

b) Data sekunder yaitu data yang diperoleh dari catatan rekam medik di wilayah kerja Puskesmas Kedungmundu Semarang tahun 2016.

\section{HASIL}

\section{Gambaran Umum Penelitian}

Penelitian ini mengenai hubungan pola makan, kondisi psikologis, dan aktivitas fisik dengan diabetes mellitus pada lansia di Puskesmas Kumai yang telah dilakukan pada 06 Desember 2016 - 01 Januari 2017, dengan jumlah sampel yang memenuhi kriteria inklusi dan ekslusi dan telah ditentukan berjumlah 165 orang. 
Sesuai dengan tujuan umum yaitu untuk mempelajari dan menjelaskan penyebab kejadian diabetes mellitus pada lansia di Puskesmas Kumai tahun 2017. Sebagai variabel independen kondisi psikologis, pola makan, aktivitas fisik, diabetes mellitus sebagai variabel dependen, sementara umur, jenis kelamin, suku dan pendidikan merupakan variabel perancu. Sedangkan untuk tujuan khusus penelitian yaitu untuk mempelajari dan menjelaskan tentang hubungan antara pola makan, kondisi psikologis, aktivitas fisik, umur, jenis kelamin, suku, dan pendidikan dengan kejadian diabetes mellitus pada lansia di Puskesmas Kumai tahun 2016.

\section{Gambaran Tempat Penelitian}

Puskesmas Kumai merupakan yang melayani rawat inap, selain itu juga terdapat pelayanan kesehatan ibu dan anak (KIA), pelayanan pemeriksaan kehamilan (ANC), pelayanan keluarga berencana (KB), balai pengobatan umum (BP Umum), balai pengobatan gigi (BP Gigi), pelayanan imunisasi, laboratorium, konsultasi gizi, ruang farmasi / obat, dan MTBS (Manajemen Terpadu Balita Sakit), dan pelayanan kesehatan dan lanjut usia. Tenaga medis yang memberikan pelayanan di wilayah kerja puskesmas Kumai ini terdiri dari dokter umum 5 orang (termasuk Kepala Puskesmas), dokter gigi 2 orang, kepala TU 1 orang, surveilen epid 1 orang, promosi kesehatan 1 orang, bidan 6 orang, perawat umum 7 orang, petugas gizi (AKZI) 1 orang, analis 2 orang, asisten apoteker (AA) 2 orang, perawat gigi 2 orang, hygiene sanitasi (AKL) 1 orang, tata usaha 5 orang, dan wiyakta bakti 1orang. Memiliki posyandu balita sebanyak 87 orang, posyandu lansia sebanyak 51 posyandu, dan kader aktif 405 orang.

Puskesmas Kumai terdiri dari ruang Ka. Puskesmas, ruang TU, poli umum, poli gigi, poli lansia, poli KIA, UGD, ruang $\mathrm{VK}$, ruang laboratorium, ruang periksa, apotik, loket, ruang rawat inap, ruang jaga untuk petugas, kamar mandi petugas dan pasien serta dapur.

\section{Hasil Analisis Univariat}

Hasil analisis yang dilakukan bertujuan untuk mengetahui distribusi frekuensi dari masing-masing variabel yang di teliti, meliputi variabel dependent (diabetes mellitus), variabel independent (pola makan, kondisi psikologis, aktivitas fisik), dan karakteristik responden (umur, jenis kelamin, suku dan pendidikan). Secara jelas hasil analisis univariat akan disajikan dalam beberapa tabel berikut :

\section{Gambaran Kejadian Diabetes Mellitus Pada Lansia di Wilayah Kerja Puskesmas Kumai}

Tabel 1.1 Distribusi Frekuensi Berdasarkan Kejadian Diabetes Mellitus

\begin{tabular}{lll}
\hline DM & $\begin{array}{l}\text { Frekuensi } \\
(\mathbf{n})\end{array}$ & $\begin{array}{l}\text { Persentase } \\
(\boldsymbol{\%})\end{array}$ \\
\hline DM & 88 & $53.3 \%$ \\
Tidak DM & 87 & $46.7 \%$ \\
\hline Total & $\mathbf{1 6 5}$ & $\mathbf{1 0 0 \%}$ \\
\hline
\end{tabular}

Berdasarkan tabel 1.1 diketahui bahwa angka kejadian lansia yang positif DM dan tidak DM hampir sama banyak yakni $53.3 \%$ dan $46.7 \%$.

\section{Gambaran Pola Makan Pada Lansia Terhadap Kejadian Diabetes Mellitus.}

Tabel 1.2 Distribusi Frekuensi Berdasarkan Pola Makan

\begin{tabular}{lll}
\hline $\begin{array}{l}\text { Pola } \\
\text { Makan }\end{array}$ & $\begin{array}{l}\text { Frekuensi } \\
(\mathbf{n})\end{array}$ & $\begin{array}{l}\text { Persentase } \\
(\boldsymbol{\%})\end{array}$ \\
\hline Sering & 89 & $53.93 \%$ \\
Jarang & 76 & $46.06 \%$ \\
\hline Total & $\mathbf{1 6 5}$ & $\mathbf{1 0 0 \%}$ \\
\hline
\end{tabular}

Berdasarkan tabel 1.2 diketahui bahwa lansia yang memiliki pola makan sering dan pola makan jarang beda proporsinya hampir sama banyak yakni $53.93 \%$ dan $46.06 \%$.

\section{Gambaran Kondisi Psikologis Lansia Terhadap Kejadian Diabetes Mellitus}


Tabel 1.3 Distribusi Frekuensi Berdasarkan Kondisi Psikologis

\begin{tabular}{llllll}
\hline $\begin{array}{l}\text { Kondisi } \\
\text { Psikologis }\end{array}$ & $\begin{array}{l}\text { Frekuensi } \\
(\mathbf{n})\end{array}$ & $\begin{array}{l}\text { Persentas } \\
\text { e (\%) }\end{array}$ & $\begin{array}{l}\text { Jenis } \\
\text { Kelamin }\end{array}$ & $\begin{array}{l}\text { Frekuensi } \\
(\mathbf{n})\end{array}$ & $\begin{array}{l}\text { Persentase } \\
(\boldsymbol{\%})\end{array}$ \\
\hline Stres & 90 & $54.5 \%$ & Perempuan & 111 & $67.3 \%$ \\
Tidak Stres & 75 & $45.5 \%$ & Laki-laki & 54 & $32.7 \%$ \\
\hline Total & $\mathbf{1 6 5}$ & $\mathbf{1 0 0 \%}$ & Total & $\mathbf{1 6 5}$ & $\mathbf{1 0 0 \%}$ \\
\hline
\end{tabular}

Berdasarkan tabel 1.3 diketahui bahwa lansia yang memiliki kondisi psikologis dengan stress dan tidak stres proporsinya $9 \%$ dan yang lebih berisiko untuk terkena diabetes mellitus adalah stress.

4. Gambaran Aktivitas Fisik Pada Lansia Terhadap Kejadian Diabetes Mellitus

Tabel 1.4 Distribusi Frekuensi

Berdasarkan Aktivitas Fisik

\begin{tabular}{lll}
\hline $\begin{array}{l}\text { Aktivitas } \\
\text { Fisik }\end{array}$ & $\begin{array}{l}\text { Frekuensi } \\
(\mathbf{n})\end{array}$ & $\begin{array}{l}\text { Persentase } \\
(\boldsymbol{\%})\end{array}$ \\
\hline Ringan & 101 & $61.2 \%$ \\
Berat & 64 & $38.8 \%$ \\
\hline Total & $\mathbf{1 6 5}$ & $\mathbf{1 0 0 \%}$ \\
\hline
\end{tabular}

Berdasarkan tabel 1.4 diketahui bahwa lansia dengan aktivitas fisik yang ringan memiliki beda proporsi dengan aktivitas berat sebesar $22 \%$, dan yang paling berhubungan terhadap diabetes mellitus adalah aktivitas yang ringan.

\section{Gambaran Umur Lansia Terhadap Kejadian Diabetes Mellitus}

Tabel 1.5 Distribusi Frekuensi

Berdasarkan Umur

\begin{tabular}{lll}
\hline Umur & $\begin{array}{l}\text { Frekuensi } \\
(\mathbf{n})\end{array}$ & $\begin{array}{l}\text { Persentase } \\
(\boldsymbol{\%})\end{array}$ \\
\hline Lanjut & 86 & $52.1 \%$ \\
Tua & 79 & $47.9 \%$ \\
\hline Total & $\mathbf{1 6 5}$ & $\mathbf{1 0 0 \%}$ \\
\hline
\end{tabular}

Berdasarkan tabel 1.5 diketahui bahwa lansia dengan usia lanjut dan lansia dengan usia tua memiliki beda proporsi sebesar $4 \%$ dan yang paling berisiko terkena diabetes mellitus adalah lansia dengan usia lanjut.

\section{Gambaran Jenis Kelamin Lansia Terhadap Kejadian Diabetes Mellitus}

Tabel 1.6 Distribusi Frekuensi Jenis Kelamin

Berdasarkan tabel 1.6 diketahui bahwa lansia dengan jenis kelamin laki-laki dan lansia dengan jenis kelamin perempuan memiliki beda proporsi sebesar $34 \%$, dan yang lansia berjenis kelamin perempuan yang lebih berisiko untuk terkena diabetes mellitus.

\section{Gambaran Suku Lansia}

Terhadap Kejadian Diabetes Mellitus

Tabel 1.7 Distribusi Frekuensi Suku

\begin{tabular}{lll}
\hline Suku & $\begin{array}{l}\text { Frekuensi } \\
(\mathbf{n})\end{array}$ & $\begin{array}{l}\text { Persentase } \\
(\boldsymbol{\%})\end{array}$ \\
\hline Jawa & 118 & $71.5 \%$ \\
Non Jawa & 47 & $28.5 \%$ \\
\hline Total & $\mathbf{1 6 5}$ & $\mathbf{1 0 0 \%}$ \\
\hline
\end{tabular}

Berdasarkan tabel 1.7 diketahui bahwa lansia dengan suku Jawa dan lansia dengan suku Non Jawa memiliki beda proporsi sebesar $42 \%$ dan paling berisiko terkena diabetes mellitus adalah lansia yang bersuku jawa.

8. Gambaran Pendidikan Lansia Terhadap Kejadian Diabetes Mellitus Tabel 1.8 Distribusi Frekuensi Pendidikan

\begin{tabular}{lll}
\hline Pendidikan & $\begin{array}{l}\text { Jumlah } \\
\text { (n) }\end{array}$ & $\begin{array}{l}\text { Persentas } \\
\text { e(\%) }\end{array}$ \\
\hline Rendah & 120 & $73.5 \%$ \\
Tinggi & 45 & $26.6 \%$ \\
\hline Total & $\mathbf{1 6 5}$ & $\mathbf{1 0 0 \%}$ \\
\hline
\end{tabular}

Berdasarkan tabel 1.8 diketahui bahwa lansia dengan tingkat pendidikan rendah dan lansia dengan tingkat pendidikan rendah memiliki beda proporsi sebesar $46 \%$ dan paling berisiko terkena diabetes mellitus adalah lansia dengan tinggkat pendidikan rendah. 


\section{Analisis Bivariat}

Analisis secara bivariat menjelaskan tentang hubungan satu variabel independen terhadap satu variabel dependen. Variabel dalam penelitian yaitu Diabetes pada lansia, kondisi psikologis, pola makan, dan aktifitas fisik. Metode yang digunakan adalah uji chi-square, dengan taraf kepercayaan 95\% (nilai $\mathrm{p}=$ $0.05)$.

\section{Hubungan Pola Makan}

\begin{tabular}{|c|c|c|c|c|c|c|c|}
\hline $\begin{array}{l}\text { Serin } \\
(>3 x)\end{array}$ & $\begin{array}{c}61 \\
5 \%\end{array}$ & & & $89(3$ &.$(5$ & $\%)$ & \\
\hline hari) & ) & ) & & & & & \\
\hline Jara & 27 & 49 & 76 & 3.9 & 2.0 & 7.5 & 0.001 \\
\hline ng & (35. & (64. & $(46 \%)$ & 54 & 67 & 64 & \\
\hline$(<3 x /$ & $5 \%$ & $5 \%$ & & & & & \\
\hline hari) & ) & ) & & & & & \\
\hline Total & 88 & 77 & 165 & & & & \\
\hline & (53. & (46. & $(100$ & & & & \\
\hline & $3 \%$ & $7 \%$ & $\%)$ & & & & \\
\hline & ) & ) & & & & & \\
\hline
\end{tabular}

Tabel 1.9 menyajikan analisis bivariat tentang pola makan lansia terhadap DM, didapatkan nilai chi-square hitung Odds ratio (OR) sebesar 3.954 dengan nilai $\mathrm{p}=0.001 ; \mathrm{CI}(95 \%)=2.067-7.564$. Proporsinya pola makan sering sebesar $54 \%$ dan pola makan jarang sebesar $46 \%$, beda proporsinya sebesar $8 \%$. Lansia yang memiliki pola makan karbohidrat sering memiliki peluang risiko terkena diabetes mellitus 4 kali lebih tinggi dibandingkan dengan lansia yang memiliki pola makan karbohidrat jarang. Hal ini menunjukkan terdapat hubungan yang signifikan antara pola makan lansia terhadap diabetes mellitus.

\section{Hubungan Kondisi Psikologis}

Tabel 1.10 Hubungan Kondisi Psikologis dengan Diabetes pada Lansia

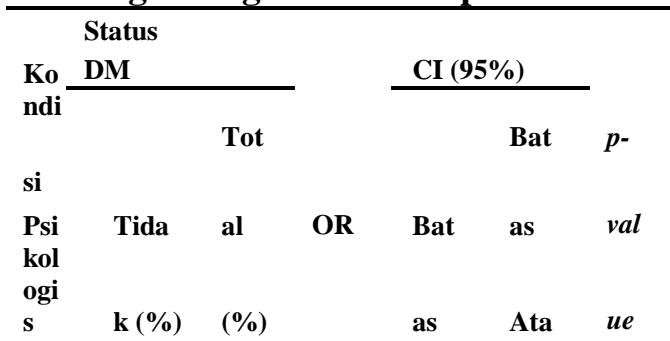

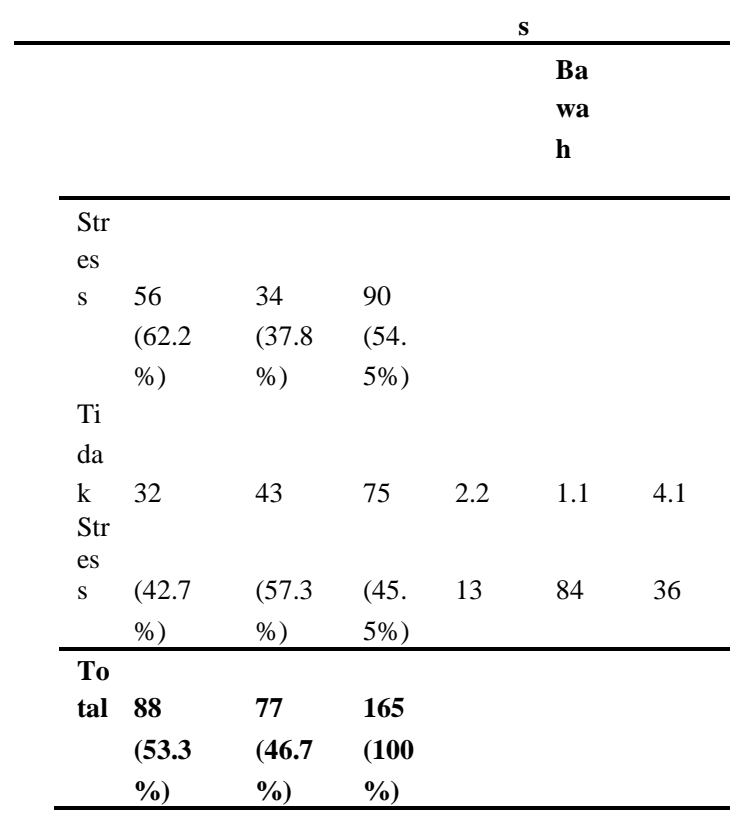

Pada tabel 1.10 Menyajikan analisis bivariat tentang kondisi psikologis lansia terhadap DM, didapatkan nilai chi-square hitung Odds ratio (OR) sebesar 2.213 dengan nilai $\mathrm{p}=0.012$; $\mathrm{CI}(95 \%)=1.184-4.136$. Proporsi stress sebesar $(54.5 \%)$ dan tidak stress sebesar (45.5\%), beda proporsinya sebesar (9\%). Lansia yang memiliki kondisi psikologis dengan stress memiliki peluang risiko terkena diabetes mellitus 2.2 kali lebih tinggi dibandingan dengan lansia tidak stress. Hal ini menunjukkan terdapat hubungan yang signifikan antara kondisi psikologis lansia terhadap Diabetes Mellitus.

\section{Hubungan Aktivitas Fisik}

Tabel 1.11 Hubungan Aktivitas Fisik dengan Diabetes pada Lansia

\begin{tabular}{|c|c|c|c|c|c|c|c|}
\hline \multirow[b]{2}{*}{ Aktivit } & \multicolumn{3}{|c|}{ Status DM } & & \multicolumn{2}{|c|}{ CI $(95 \%)$} & \multirow[b]{3}{*}{$p-$} \\
\hline & & & Tot & & Bat & & \\
\hline as & & & al & & as & Bat & \\
\hline \multirow{4}{*}{ Fisik } & Ya & Tida & & OR & & as & val \\
\hline & $(\%)$ & $\mathbf{k}(\%)$ & $(\%)$ & & $\mathbf{B a}$ & Ata & ue \\
\hline & & & & & & $\mathbf{S}$ & \\
\hline & & & & & h & 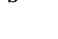 & \\
\hline \multirow[t]{2}{*}{ Ringan } & 63 & 38 & 101 & & & & \\
\hline & $(62.4$ & $(37.6$ & (61. & & & & \\
\hline
\end{tabular}




\begin{tabular}{llllllll} 
& $\%)$ & $\%)$ & $2 \%)$ & & & & \\
Berat & 25 & 39 & 64 & 2.5 & 1.3 & 4.9 & 0.0 \\
& $(39.1$ & $(60.9$ & $(38$. & 86 & 59 & 23 & 03 \\
& $\%)$ & $\%)$ & $8 \%)$ & & & & \\
\hline Total & $\mathbf{8 8}$ & $\mathbf{7 7}$ & $\mathbf{1 6 5}$ & & & \\
& $\mathbf{( 5 3 . 3}$ & $\mathbf{( 4 6 . 7}$ & $(\mathbf{1 0 0}$ & & & \\
& $\mathbf{\% )}$ & $\mathbf{\% )}$ & $\mathbf{\% )}$ & & & \\
\hline
\end{tabular}

Tabel 1.11 Menyajikan analisis bivariat tentang aktivitas fisik lansia terhadap DM, didapatkan nilai chi-square hitung Odds ratio (OR) sebesar 2.586 dengan nilai $\mathrm{p}=0.003 ; \mathrm{CI}(95 \%)=1.359$

- 4.923. Proporsi aktivitas fisik ringan sebesar $(61.2 \%)$ dan aktivitas berat sebesar $(38.8 \%)$, beda proporsinya sebesar (22.4\%). Lansia yang memiliki aktivitas fisik ringan mempunyai peluang risiko terkena diabetes mellitus 2.5 kali lebih tinggi dibandingkan dengan lansia yang memiliki aktivitas berat. Hal ini menunjukkan terdapat hubungan yang signifikan antara aktivitas fisik lansia terhadap Diabetes Mellitus.

\section{Hubungan Umur}

Tabel 1.12 Hubungan Umur dengan Diabetes pada Lansia

\begin{tabular}{|c|c|c|c|c|c|c|}
\hline & \multicolumn{3}{|c|}{ Status DM } & \multicolumn{2}{|c|}{ CI $(95 \%)$} & \multirow[b]{2}{*}{$p-$} \\
\hline & & & Tot & & Bat & \\
\hline \multicolumn{7}{|l|}{ Um } \\
\hline & Ya & Tida & alOR & Bat & as & val \\
\hline \multirow{2}{*}{$\mathbf{U r}$} & $(\%)$ & k $(\%)$ & $(\%)$ & as & Ata & ue \\
\hline & & & & & & \\
\hline
\end{tabular}

\begin{tabular}{ll}
\hline Ba \\
wa \\
h
\end{tabular}

\begin{tabular}{llllllll}
\hline Lan & 53 & 33 & 86 & & & \\
jut & $(61.6$ & $(38.4$ & $(52$. \\
& $\%)$ & $\%)$ & $2 \%)$ & & & \\
Tua & 35 & 44 & 79 & 2.0 & 1.0 & 3.7 & 0.0 \\
& $(44.3$ & $(55.7$ & $(47$. & 19 & 85 & 58 & 26 \\
& $\%)$ & $\%)$ & $8 \%)$ & & & \\
\hline Tot & $\mathbf{8 8}$ & $\mathbf{7 7}$ & $\mathbf{1 6 5}$ & & & & \\
& & $\mathbf{1 0}$ \\
al & $\mathbf{( 5 3 . 3}$ & $\mathbf{( 4 6 . 7} \mathbf{0}$
\end{tabular}

$$
\text { \%) \%) \%) }
$$

Tabel 1.12 Menyajikan analisis bivariat tentang umur lansia terhadap DM, didapatkan nilai chi-square hitung Odds ratio (OR) sebesar 2.019 dengan nilai $\mathrm{p}=0.0026 ; \mathrm{CI}(95 \%)=1.085-$ 3.758. Proporsi umur lanjut sebesar $(52.2 \%)$ dan umur tua sebesar $(47.8 \%)$, beda proporsinya sebesar (4.4\%). Lansia dengan umur lanjut (60-75 tahun) memiliki peluang risiko terkena diabetes mellitus 2 kali lebih tinggi dibandingkan lansia dengan umur tua (76-90 tahun). Hal ini menunjukkan terdapat hubungan yang signifikan antara umur lansia terhadap Diabetes Mellitus.

\section{Hubungan Jenis Kelamin}

Tabel 1.13 Hubungan Jenis Kelamin dengan Diabetes pada Lansia

\begin{tabular}{|c|c|c|c|c|c|c|c|}
\hline Jeni & \multicolumn{3}{|c|}{ Status DM } & & \multicolumn{3}{|c|}{ CI $(95 \%)$} \\
\hline $\mathbf{s}$ & & & $\begin{array}{l}\text { Total } \\
(\%)\end{array}$ & & $\begin{array}{l}\text { Bat } \\
\text { as }\end{array}$ & Bat & $\begin{array}{l}p \\
- \\
v\end{array}$ \\
\hline Kela & Ya (\%) & Tidak & & OR & $\mathbf{B a}$ & as & $u$ \\
\hline $\min$ & & $(\%)$ & & & $\begin{array}{l}\text { wa } \\
\text { h }\end{array}$ & $\begin{array}{l}\text { Ata } \\
\mathrm{s}\end{array}$ & $e$ \\
\hline $\begin{array}{l}\text { Pere } \\
\text { mpu } \\
\text { an }\end{array}$ & $\begin{array}{l}67 \\
(60.4 \% \\
)\end{array}$ & $\begin{array}{l}44 \\
(39.6 \% \\
)\end{array}$ & $\begin{array}{l}108 \\
(65.3 \% \\
)\end{array}$ & & & & \\
\hline Laki- & 21 & 33 & 54 & 2.3 & 1.2 & 4.6 & 0 \\
\hline laki & $\begin{array}{l}(38.9 \% \\
)\end{array}$ & $\begin{array}{l}(61.1 \% \\
)\end{array}$ & $\begin{array}{l}(34.7 \% \\
)\end{array}$ & 93 & 29 & 59 & 9 \\
\hline Total & $\begin{array}{l}88 \\
(53.3 \% \\
)\end{array}$ & $\begin{array}{l}77 \\
(46.7 \% \\
)\end{array}$ & $\begin{array}{l}165 \\
(100 \%)\end{array}$ & & & & \\
\hline
\end{tabular}

Diabetes Mellitus.

\section{Hubungan Suku}

Tabel 1.14 Hubungan Suku dengan Diabetes pada Lansia

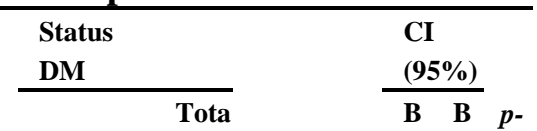




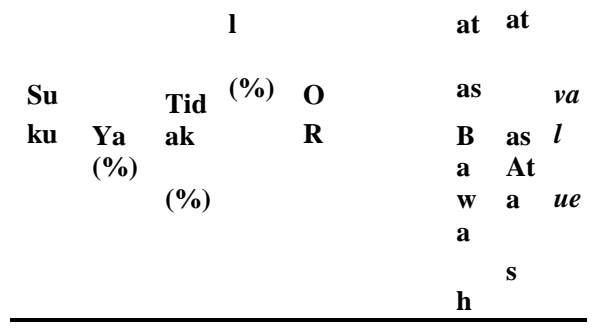

$$
\begin{array}{cccc}
\hline \text { Jawa } & 73 & 45 & 118 \\
& (61 . & (38 . & (71 . \\
9 \% & 1 \% & 5 \%
\end{array}
$$

1. 7.0.

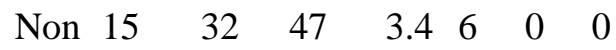$$
\text { Jaw (31.9) (68. (28.5 }
$$$$
\begin{array}{llllllll}
\text { a } & \% & 1 \% & \% & 61 & 90 & 89 & 01
\end{array}
$$

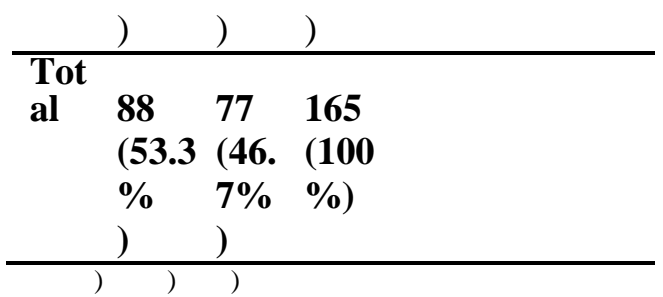

Pada tabel 1.13 Menyajikan analisis bivariat tentang jenis kelamin lansia terhadap DM, didapatkan nilai chi-square hitung Odds ratio (OR) sebesar 2.393 dengan nilai $\mathrm{p}=0.009 ; \mathrm{CI}(95 \%)=$ 1.229 - 4.659. Proporsi jenis kelamin perempuan sebesar $(65.3 \%)$ dan jenis kelamin laki-laki sebesar (34.7\%), beda proporsi nya sebesar (30.6\%). Lansia yang berjenis kelamin perempuan memiliki peluang risiko terkena diabetes mellitus 2.3 kali lebih tinggi dibandingkan dengan lansia berjenis kelamin laki-laki. Hal ini menunjukkan terdapat hubungan yang signifikan antara jenis kelamin lansia terhadap

Pada tabel 1.14 Menyajikan analisis bivariat tentang suku lansia terhadap DM, didapatkan nilai chi-square hitung Odds ratio (OR) sebesar 3.461 dengan nilai $\mathrm{p}=0.001 ; \mathrm{CI}(95 \%)=$ 1.690 - 7.089. Proporsi suku Jawa sebesar $(71.5 \%)$ dan proporsi suku Non Jawa sebesar (28.5\%) beda proporsinya sebesar (43\%). Lansia dengan suku Jawa memiliki peluang risiko terkena diabetes mellius 3.4 kali lebih tinggi dibandingkan lansia yang bersuku Non Jawa. Hal ini menunjukkan bahwa ada hubungan yang signifikan antara suku lansia terhadap Diabetes Mellitus.

\begin{tabular}{|c|c|c|c|c|c|c|c|}
\hline \multirow{7}{*}{$\begin{array}{l}\text { Pend } \\
\text { idika } \\
\text { n }\end{array}$} & \multicolumn{3}{|c|}{ Status DM } & \multirow{7}{*}{ OR } & \multicolumn{2}{|c|}{ CI $(95 \%)$} & \multirow[b]{3}{*}{$p-$} \\
\hline & \multirow{3}{*}{ Ya } & & Tot & & Bat & \multirow{3}{*}{$\begin{array}{l}\text { Bat } \\
\text { as }\end{array}$} & \\
\hline & & \multirow{5}{*}{$\begin{array}{l}\text { Tida } \\
\mathbf{k} \\
(\%)\end{array}$} & & & & & \\
\hline & & & dil & & ds & & \multirow{4}{*}{ val } \\
\hline & $(\%)$ & & $(\%)$ & & $\mathbf{B a}$ & Ata & \\
\hline & & & & & & \multirow{2}{*}{$\mathbf{S}$} & \\
\hline & & & & & h & & \\
\hline \multirow{3}{*}{$\begin{array}{l}\text { Rend } \\
\text { ah }\end{array}$} & 72 & 48 & 120 & & & & \\
\hline & $(60.0$ & $(40.0$ & (72. & & & & \\
\hline & $\%)$ & $\%)$ & $7 \%)$ & & & & \\
\hline \multirow{3}{*}{$\begin{array}{l}\text { Ting } \\
\text { gi }\end{array}$} & 16 & 29 & 45 & 2.7 & 1.3 & 5.5 & 0.0 \\
\hline & (35.6 & $(64.4$ & $(27$. & 19 & 35 & 37 & 05 \\
\hline & $\%)$ & $\%)$ & $3 \%)$ & & & & \\
\hline \multirow[t]{3}{*}{ Total } & 88 & 77 & 165 & & & & \\
\hline & $(53.3$ & (46.7 & $(100$ & & & & \\
\hline & $\%)$ & $\%)$ & $\%)$ & & & & \\
\hline
\end{tabular}

\section{Hubungan Pendidikan}

Tabel 1.15 Hubungan Pendidikan dengan Diabetes pada Lansia

Pada tabel 1.15 Menyajikan analisis bivariat tentang pendidikan lansia terhadap DM, didapatkan nilai chisquare hitung Odds ratio (OR) sebesar 2.719 dengan nilai $\mathrm{p}=0.005$; CI $(95 \%)=1.335-5.537$. Proporsi pendidikan rendah sebesar $(72.7 \%)$ dan pendidikan tinggi sebesar (27.3\%), beda proporsi nya sebesar $(45.4 \%)$ Lansia yang memiliki pendidikan rendah memiliki peluang risiko terkena diabetes mellitus 2.7 kali lebih tinggi dibandingkan dengan lansia yang memiliki pendidikan rendah. Hal ini menunjukkan terdapat hubungan yang signifikan antara pendidikan lansia terhadap Diabetes Mellitus.

\section{Analisis Multivariat}

Setelah dilakukan analisis bivariat, selanjutnya dilakukan analisis multivariat yang bertujuan untuk mengetahui hubungan paling dominan antara variabel satu dengan 
variabel yang lain. Tahap awal multivariat adalah penentu variabel potensial (variabel kandidat multivariat) yang akan masuk dalam analisis multivariat, yaitu variabel dari hasil analisis bivariat yang mempunyai nilai $p$-value $<0,25$ (Lameshow, 1990).

Analisis multivariat yang digunakan dalam penelitian ini adalah Regresi Logistik. Berikut ini tabel seleksi bivariat dengan menggunakan regresi logistik sederhana :

Tabel 1.16 Variabel Seleksi Bivariat Masing - Masing Variabel Untuk Kandidat Model Multivariat

\begin{tabular}{lll}
\hline Variabel & $\boldsymbol{P}$-value & Keterangan \\
\hline 1. Pola Makan & 0.000 & Kandidat \\
2. Kondisi & 0.011 & Kandidat \\
$\begin{array}{l}\text { Psikologis } \\
\quad 0.004\end{array}$ & Kandidat \\
Aktivitas & & \\
3. Fisik & 0.001 & Kandidat \\
\hline
\end{tabular}

\begin{tabular}{lll}
\hline 4. Umur & 0.003 & Kandidat \\
Jenis & & \\
5. Kelamin & 0.009 & Kandidat \\
6. Suku & 0.005 & Kandidat \\
7. Pendidikan & & \\
\hline
\end{tabular}

Berdasarkan Tabel 1.16 hasil analisis bivariat diatas menunjukkan bahwa variabel dengan nilai $p$-value $<0,25$ dan semua masuk ke dalam model multivariat yaitu variabel pola makan, kondisi psikologis, aktivitas fisik, umur, jenis kelamin, suku dan pendidikan.

Hasil analisis regresi logistik ganda dapat dilihat pada tabel berikut :

\begin{tabular}{|c|c|c|c|}
\hline No. & Variabel & $p$-value & OR \\
\hline 1. & Pola Makan & 0.007 & 2.896 \\
\hline 2. & Kondisi & 0.013 & 0.371 \\
\hline 3. & Psikologis & 0.250 & 0.589 \\
\hline 4. & Aktivitas Fisik & 0.432 & 1.416 \\
\hline 5. & Umur & 0.036 & 0.396 \\
\hline 6. & Jenis & 0.000 & 0.174 \\
\hline \multirow[t]{3}{*}{7.} & Kelamin & 0.018 & 0.363 \\
\hline & Suku & & \\
\hline & Pendidikan & & \\
\hline
\end{tabular}

Dari hasil analisis diatas terlihat ada 5 variabel yang $p$-value nya $<0.05$ yaitu variabel pola makan, kondisi psikologis, jenis kelamin, suku dan pendidikan. Dan kemudian dikeluarkan variabel dengan $p$-value yang lebih tinggi terlebih dahulu yaitu variabel umur dengan nilai $p$-value 0.432, sehingga pemodelan selanjutnya untuk variabel umur dikeluarkan dari model.

Pada waktu variabel umur dikeluarkan dilihat perubahan nilai OR seperti yang terlihat pada tabel sebagai berikut:

Tabel 1.18 Hasil Analisis Regresi Logistik Antara Variabel Pola Makan, Kondisi Psikologis, Aktivitas Fisik, Jenis Kelamin, Suku dan Pendidikan

\begin{tabular}{llll}
\hline No. & Variabel & p-value & OR \\
\hline 1. & Pola Makan & 0.006 & 2.950 \\
2. & Kondisi & 0.012 & 0.367 \\
3. & Psikologis & 0.113 & 0.511 \\
4. & Aktivitas Fisik & 0.027 & 0.378 \\
5. & Jenis Kelamin & 0.000 & 0.174 \\
6. & Suku & 0.012 & 0.346 \\
& Pendidikan & & \\
\hline
\end{tabular}

Selanjutnnya dilihat perubahan OR, sebagai berikut :

Tabel 1.19 Hasil Analisis

Perubahan OR Pada

Variabel Umur Setelah di

Keluarkan dari Model

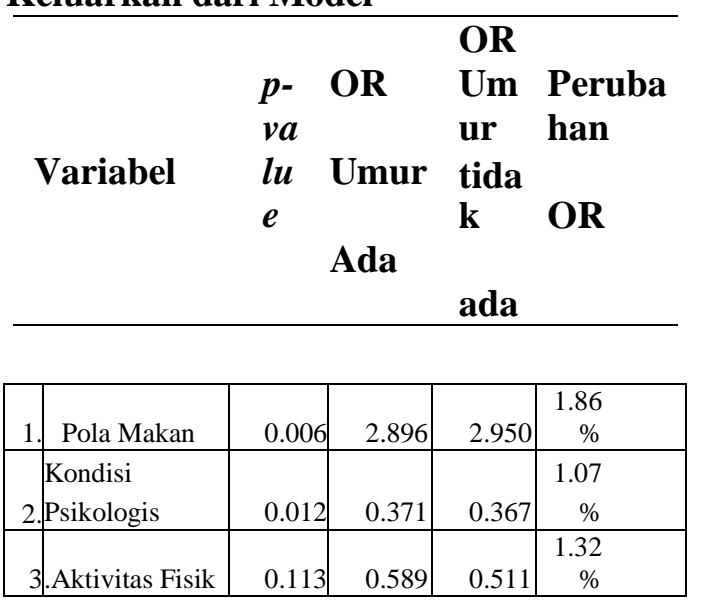




\begin{tabular}{|r|l|c|c|c|c|}
\hline 4. & Jenis Kelamin & 0.027 & 0.396 & 0.378 & $\begin{array}{c}4.54 \\
\%\end{array}$ \\
\hline 5. Suku & 0.000 & 0.174 & 0.174 & $\begin{array}{c}0.00 \\
\%\end{array}$ \\
\hline 6. & Pendidikan & 0.012 & 0.363 & 0.346 & $\begin{array}{c}4.68 \\
\%\end{array}$ \\
\hline
\end{tabular}

Dari analisis perbandingan OR, ternyata perubahannya $<10 \%$ dengan demikian variabel umur dari model. Kemudian lihat lagi $p$-value $>0,05$ yaitu variabel aktivitas fisik dikeluarkan dari model, kemudian dianalisis dan hasilnya :

Tabel 1.20 Hasil Analisis Regresi Logistik

Antara Variabel Pola Makan, Kondisi Psikologis,

Umur, Jenis Kelamin, Suku dan Pendidikan

\begin{tabular}{llll}
\hline No. & Variabel & p-value & OR \\
\hline 1. & Pola Makan & 0.004 & 3.103 \\
2. & Kondisi & 0.007 & 0.348 \\
3. & Psikologis & 0.003 & 0.296 \\
4. & Jenis Kelamin & 0.000 & 0.194 \\
5. & Suku & 0.003 & 0.293 \\
& Pendidikan & & \\
\hline
\end{tabular}

Selanjutnnya dilihat perubahan OR, sebagai berikut :

Tabel 1.21 Hasil Analisis

Perubahan OR Pada

Variabel Umur Setelah di

Keluarkan dari Model

\begin{tabular}{|c|c|c|c|c|}
\hline Variabel & $\begin{array}{l}p- \\
\text { valu } \\
e\end{array}$ & $\begin{array}{l}\text { OR } \\
\text { AF } \\
\text { Ada }\end{array}$ & $\begin{array}{l}\text { OR } \\
\text { AF tidak } \\
\text { ada }\end{array}$ & $\begin{array}{l}\text { Peruba } \\
\text { han OR }\end{array}$ \\
\hline \multirow{2}{*}{$\begin{array}{l}\text { 1. Pola } \\
\text { Makan }\end{array}$} & 0.00 & 2.89 & 3.103 & $7.14 \%$ \\
\hline & 4 & 6 & 0.348 & $6.19 \%$ \\
\hline \multirow{2}{*}{$\begin{array}{l}\text { 2. Kondisi } \\
\text { Psikologis }\end{array}$} & 0.00 & 0.37 & 0.296 & $25.2 \%$ \\
\hline & 7 & 1 & 0.194 & $11.49 \%$ \\
\hline \multirow{2}{*}{$\begin{array}{l}\text { 3. Jenis } \\
\text { Kelamin }\end{array}$} & 0.00 & 0.39 & 0.293 & $19.28 \%$ \\
\hline & 3 & 6 & & \\
\hline 4. Suku & 0.00 & 0.17 & & \\
\hline \multirow{3}{*}{$\begin{array}{l}\text { 5. Pendidika } \\
\mathrm{n}\end{array}$} & 0 & 4 & & \\
\hline & 0.00 & 0.36 & & \\
\hline & 3 & 3 & & \\
\hline
\end{tabular}

Dari analisis perbandingan OR, ternyata perubahannya $>10 \%$ dengan demikian variabel aktivitas fisik dimasukkan kembali ke dalam model. kemudian dianalisis dan hasilnya :

Tabel 1.22 Tabel Akhir Analisis Multivariat

\begin{tabular}{llll}
\hline No. & Variabel & p-value & OR \\
\hline 1. & Pola Makan & 0.006 & 2.950 \\
2. & Kondisi & 0.012 & 2.726 \\
3. & Psikologis & 0.027 & 2.649 \\
& Jenis & & \\
4. & Kelamin & 0.000 & 2.756 \\
5. & Suku & 0.012 & 2.893 \\
6. & Pendidikan & 0.113 & 1.958 \\
& Aktivitas & & \\
& Fisik & & \\
\hline
\end{tabular}

Setelah itu dilihat nilai OR paling tinggi yaitu terdapat pada variabel pola makan, maka faktor dominan dari kejadian diabetes mellitus adalah pola makan setelah di kontrol oleh variabel pendidikan. Variabel Aktivitas fisik merupakan variabel confounding karena p-value $>0.005$. Kemudian dari hasil analisis multivariat diperoleh variabel yang berhubungan dan bermakna dengan status diabetes mellitus adalah variabel kondisi psikologis, jenis kelamin, dan suku. Hasil analisis di dapatkan OR pada variabel pola makan adalah 2.950 artinya pola makan karbohidrat sering memiliki peluang sebanyak 3 kali lebih tinggi dibandingkan pola makan karbohidrat yang jarang.

\section{PEMBAHASAN}

Setelah dilakukan pengolahan, analisis dan penyajian data, dilakukan pembahasan hasil penelitian sesuai dengan variabel yang diteliti. Hasil penelitian yang telah peneliti dapatkan sesuai dengan hasil penelitian alur kerangka konsep yang ada, dengan menghubungkan teori dan temuan peneliti sebelumnya.

\section{Hubungan Pola Makan Dengan Kejadian Diabetes Mellitus Pada Lansia}

Hasil analisis dari 165 lansia di Puskesmas Kumai menunjukkan terdapat hubungan antara pola makan dengan risiko lansia yang mengalami Diabetes Mellitus dan 
secara statistik signifikan. Uji analisis dengan menggunakan chi square di peroleh p-value sebesar 0.001 ( $\mathrm{p}$-value <0.005), dengan nilai OR

$=3.954$. Artinya lansia yang memiliki pola makan sering mempunyai peluang risiko 4 kali lebih tinggi untuk menderita diabetes mellitus dibanding dengan lansia yang memiliki pola makan jarang. Hal ini sejalan dengan hasil penelitian Rahmawati (2011) tentang hubungan pola makan dan aktivitas dengan kadar glukosa darah penderita diabetes melitus tipe-2 rawat jalan di RSUP Dr. Wahidin Sudirohusodo Makassar, dari hasil penelitiannya, peningkatan glukosa darah pada penderita DM tipe-2 lebih tinggi pada responden yang memiliki pola makan kurang baik ada $87,9 \%$ atau 29 orang dari 55 orang sebagai sampel. Hasil yang di dapatkan menunjukkan bahwa ada hubungan pola makan dengan kejadian Diabetes Melitus tipe-2 dengan nilai p 0,000 .

\section{Hubungan Kondisi Psikologis Dengan Kejadian Diabetes Mellitus Pada Lansia}

Hasil penelitian menunjukkan terdapat hubungan antara kondisi psikologis terhadap risiko lansia yang mengalami Diabetes Mellitus dan secara statistik signifikan, dengan $p$-value 0.012 , dan OR 2.213. Lansia yang memiliki kondisi psikologis dengan tingkat stress berat dapat mengalami DM 2 kali lebih tinggi daripada lansia yang memiliki kondisi psikologis dengan tingkat stress ringan. Penelitian ini sejalan dengan penelitian yang dilakukan oleh Septian Adi Nugroho (2010) tentang Hubungan Antara Tingkat Stres Dengan Kadar Gula Darah Pada Pasien Diabetes Melitus Di Wilayah Kerja Puskesmas Sukoharjo I Kabupaten Sukoharjo, dari hasil penelitiannya menunjukkan adanya hubungan tingkat stres dengan kadar gula darah pasien diabetes mellitus di wilayah kerja Puskesmas Sukoharjo I.

Ketua Perkumpulan Endokrinologi Indonesia (PERKENI) yang juga Presiden AFES, dr. Sidartawan Soegondo SpPD-
KE, yang mengemukakan bahwa peningkatan angka kejadian diabetes tipe II di Indonesia sebagian besar disebabkan oleh pola makan yang tidak sehat, gaya hidup yang salah dan pertambahan usia harapan hidup (Sidartawan, 2007).

Secara psikologis seseorang yang terkena penyakit DM cenderung tidak dapat menerima kenyataan akan penurunan kemampuan dirinya akibat DM yang diderita yang dideritanya, tidak menutup kemungkinan munculnya gangguan psikologis yang akhirnya membawa dampak buruk bagi penyakit diabetesnya. Pada saat mereka menghadapi kenyataan bahwa penyakit tersebut tidak dapat disembuhkan mereka sulit untuk menikmati kehidupan karena harus mengendalikan penyakit diabetes yang dideritanya. Hal ini berlanjut bagaimana individu memandang masa depannya. Sikap pesimis terhadap masa depan dan kurangnya kenyakinan diri menyebabkan timbulnya rasa khawatir akan masa depan dan menimbulkan kecemasan (Sidartawan, 2007).

\section{Hubungan Aktivitas Fisik Dengan Kejadian Diabetes Mellitus Pada Lansia}

Hasil penelitian menunjukkan adanya hubungan aktivitas fisik yang secara statistik signifikan antara aktivitas fisik lansia dan risiko lansia untuk mengalami Diabetes Mellitus dengan p-value 0.003 dan nilai Odss Ratio 2.586. Hal ini sejalan dengan penelitian yang dilakukan oleh Gumilang Mega (2014) tentang hubungan aktivitas fisik dengan kadar gula darah pada pasien Diabetes Mellitus Tipe 2 di Rumah Sakit Umum Daerah Karaganyar, hasil penelitiannya menyatakan bahwa ada hubungan yang signifikan antara aktivitas fisik dengan kadar gula darah pada pasien Diabetes Mellitus Tipe 2 Di Rumah Sakit Umum Daerah Karanganyar dengan $p$ value $=0,001$ dan Odds Ratio $=0,433$.

Lansia yang memiliki aktivitas fisik yang berat dapat menurunkan risiko terkena DM 2.6 kali lebih tinggi daripada lansia yang 
memiliki aktivitas ringan. Proses penyerapan glukosa oleh jaringan tubuh saat istirahat membutuhkan insulin, sedangkan pada otot yang aktif tidak disertai kenaikan kadar insulin walaupun kebutuhan glukosa meningkat. Hal ini dikarenakan pada waktu seseorang beraktivitas fisik, terjadi peningkatan kepekaan reseptor insulin di otot yang aktif. Masalah utama yang terjadi pada diabetes mellitus tipe 2 adalah terjadinya resistensi insulin yang menyebabkan glukosa tidak dapat masuk ke dalam sel. Saat seseorang melakukan aktivitas fisik, akan terjadi kontraksi otot yang pada akhirnya akan mempermudah glukosa masuk ke dalam sel. Hal tersebut berarti saat seseorang beraktivitas fisik, akan menurunkan resistensi insulin pada akhirnya akan menurunkan kadar gula darah (Ilyas, 2011).

\section{Hubungan Umur Dengan Kejadian Diabetes Mellitus Pada Lansia}

Hasil penelitian menunjukkan hubungan umur yang secara statistik signifikan antara umur lansia dan risiko lansia untuk mengalami Diabetes Mellitus dengan $p$ value 0.026 dan nilai Odds Ratio 2.019. Lansia yang memiliki umur lanjut akan mudah untuk terkena DM sebanyak 2 kali lebih tinggi daripada lansia yang memiliki umur tua. Hal ini sejalan dengan penelitian yang dilakukan oleh Dita Garnita (2012) tentang faktor risiko diabetes mellitus di Indonesia (Analisis Data Sakerti 2007), yang menyatakan bahwa terdapat hubungan yang signifikan antara setiap kategori umur dengan kejadian Diabetes Mellitus, dan kelompok umur yang mempunyai risiko terbesar untuk mengalami diabetes adalah diatas usia 50 keatas.

Penelitian ini juga sejalan dengan penelitian yang dilakukan sebelumnya oleh Wicaksono pada tahun 2011 di RS Dr. Kariadi, Semarang didapatkan lebih dari sebagian responden berusia diatas 45 tahun. Teori mengatakan semakin bertambahnya umur, kemampuan jaringan mengambil glukosa darah semakin menurun. Diabetes Melitus tipe II lebih banyak terdapat pada orang berumur diatas 40 tahun daripada orang yang lebih muda (Suiraoka, 2012).

\section{Hubungan Jenis Kelamin Dengan Kejadian Diabetes Mellitus Pada Lansia}

Hasil penelitian menunjukkan ada hubungan dan secara statistik signifikan antara jenis kelamin dengan risiko lansia untuk mengalami Diabetes Mellitus dengan p-value 0.009 dan nilai Odds Ratio 2,393. Lansia yang berjenis kelamin perempuan akan mengalami DM 2.393 kali lebih tinggi daripada lansia yang berjenis kelamin laki-laki. Hal ini sejalan dengan hasil Riset Kesehatan Dasar 2007 menunjukkan bahwa prevalensi TGT dan DM menurut pemeriksaan gula darah perempuan lebih tinggi dibandingkan dengan laki-laki. Prevalensi TGT pada perempuan adalah $11,5 \%$ (dibandingkan dengan $8,7 \%$ pada laki-laki), sedangkan prevalensi DM pada perempuan adalah $6,4 \%$ (dibandingkan dengan $4,9 \%$ pada laki-laki).

Beckles dan Thompson Reid (2001) dalam Grant, dkk (2009) memaparkan bahwa variasi proporsi diabetes mellitus, khususnya pada wanita dapat disebabkan oleh beberapa hal, yaitu dampak dari diabetes gestasional pada ibu dan bayi, serta tingginya prevalensi diabetes mellitus pada wanita yang berusia tua, yang disebabkan oleh usia harapan hidup wanita yang lebih tinggi dari pria. Selain itu, wanita juga lebih rentan terkena faktorfaktor risiko diabetes mellitus dibandingkan dengan pria (Beckles dan Thompson Reid, 2001 dalam Grant, dkk., 2009). Factor-faktor tersebut diataranya indek masa tubuh yang serta tekanan darah yang lebih tinggi pada wanita (Juutilainen, 2004).

\section{Hubungan Suku Dengan Kejadian Diabetes Mellitus Pada Lansia}

Hasil penelitian menunjukkan ada hubungan dan secara statistik signifikan 
antara suku dan risiko lansia untuk mengalami Diabetes Mellitus dengan $p$ value 0.001 dan nilai OR 3.461. Lansia yang ber suku Jawa akan mengalami DM sebanyak 3 kali lebih tinggi daripada lansia yang ber suku Non Jawa. Pada penelitian ini suku Jawa menjadi suku yang dominan memiliki risiko lebih tinggi dibandingkan suku lain, dikarenakan pola kebiasaan makan mereka yang cenderung lebih menyukai dan memasak makanan yang dominan rasa manis.

Makanan akan menaikkan glukosa darah, satu sampai dua jam setelah makan, glukosa darah mencapai angka paling tinggi. Dengan mengatur perencanaan makan yang meliputi jumlah, jenis dan jadwal, diharapkan dapat mempertahankan kadar glukosa darah dan lipid dalam batas normal dan penderita mendapatkan nutrisi yang optimal. Sumber tenaga yang paling sering di konsumsi adalah nasi dengan frekuensi tiga kali sehari. Hal ini dikarenakan nasi merupakan sumber makanan pokok mayoritas masyarakat suku jawa, sehingga sangat susah untuk diubah agar makanan pokok ini lebih bervariasi.

\section{Hubungan Pendidikan Dengan Kejadian Diabetes Mellitus Pada Lansia}

Hasil penelitian menunjukkan adanya hubungan dan secara statistik signifikan antara tingkat pendidikan dan risiko lansia untuk mengalami Diabetes Mellitus dengan $p$-value 0.005 dengan nilai odds ratio 2.719. Dan lansia yang memiliki tingkat pendidikan rendah akan mengalami DM 3 kali lebih tinggi daripada lansia yang memiliki tingkat pendidikan tinggi. Rendahnya pendidikan dihubungkan dengan kesadaran terutama dalam kesehatan, semakin rendah kesadaran dalam kesehatan akan semakin buruk status kesehatannya. Hal ini terjadi juga pada penderita diabetes mellitus, semakin rendah pendidikannya maka akan cenderung tidak mengetahui gejala-gejala akan penyakit diabetes mellitus (Brown et $a l$, 2005). Dengan tidak diketahuinya gejala-gejala penyakit tersebut maka akan semakin berisiko terhadap kesehatannya karena tidak menyadari bahwa terdapat penyakit dalam tubuhnya.

Dan pada lansia yang memiliki tingkat pendidikan lebih tinggi, dengan pengetahuan yang mereka miliki, mereka cenderung bisa memilah dan memilih mana makanan yang memiliki banyak kalori, dan bisa mengetahui dampak dari mengkonsumsi makanan tersebut. Hal ini tidak sejalan dengan penelitian yang dilakukan oleh Isabella dkk., (2014) tentang hubungan antara tingkat pendidikan dan riwayat keluarga menderita DM dengan kejadian DM tipe 2 pada pasien rawat jalan di poliklinik penyakit dalam BLU RSUP Prof. Dr. R. D. Kandou Manado, yang menunjukkan bahwa tidak terdapat hubungan antara tingkat pendidikan dengan kejadian DM tipe 2 pada pasien rawat jalan di Poliklinik Penyakit Dalam BLU RSUP Prof. Dr. R. D. Kandou Manado.

Semakin tinggi pendidikan semakin besar kepedulian terhadap kesehatan. Namun tidak dipungkiri masih ada orang yang berpendidikan tinggi mengabaikan kesehatan dengan berbagai alasan yang menyebabkannya, salah satunya berhubungan dengan pekerjaan dimana dengan adanya kesibukan yang tinggi sehingga pola hidup yang tidak teratur atau tidak teraturnya pola makan meyebabkan gangguan kesehatan. Biasanya orang dengan kegiatan yang padat sering lupa utuk makan namun lebih banyak makan cemilan. Dengan adanya perubahan gaya hidup dan kebiasaan makan, konsumsi makanan yang tinggi energi dan tinggi lemak selain itu aktivitas fisik yang rendah, akan mengubah keseimbangan energi dengan disimpannya energi sebagai lemak simpanan yang jarang digunakan (Gibney dkk, 2009).

Tingkat pendidikan memiliki pengaruh terhadap kejadian penyakit diabetes melitus tipe 2. Orang yang tingkat pendidikannya tinggi biasanya akan memiliki banyak pengetahuan tentang kesehatan, tingkat pendidikan juga mempengaruhi aktivitas fisik seseorang 
karena terkait dengan pekerjaan yang dilakukan. Orang yang tingkat pendidikan tinggi biasanya lebih banyak bekerja di kantoran dengan aktivitas fisik sedikit sedangkan yang tingkat pendidikan rendah lebih banyak menjadi buruh maupun petani dengan aktivitas fisik yang cukup (Irawan, 2007). Berdasarkan data Riskesdas 2007, menyatakan bahwa prevalensi diabetes mellitus bervariasi pada setiap tingkat pendidikan, pada kelompok tidak sekolah prevalensi diabetes sangat besar yaitu $8,9 \%$, tidak tamat SD sebesar $8,0 \%$, tamat SD sebesar 5,5\%, tamat SMP sebesar $4,4 \%$, tamat SMA sebesar 4,9\%, dan tamat perguruan tinggi (PT) sebesar 5,6\% (Balitbangkes, 2008).

\section{SIMPULAN DAN SARAN}

\section{Simpulan}

Berdasarkan hasil penelitian dan pembahasan terhadap 165 responden di Puskesmas Kumai dapat disimpulkan sebagai berikut:

1. Di Puskesmas Kumai diketahui distribusi frekuensi yang tinggi yang memiliki peluang terbesar terkena diabetes mellitus yaitu pada variabel aktivitas fisik ringan (61.2\%), jenis kelamin perempuan (67.3\%), suku lansia yang mayoritas Jawa (71.5\%) dan variabel pendidikan lansia yang mayoritas rendah (73\%).

2. Ada hubungan antara pola makan dengan diabetes mellius setelah di kontrol oleh aktivitas fisik, jenis kelamin, suku dan pendidikan lansia. Pola makan menjadi faktor dominan pada kejadian diabetes mellitus dengan p-value 0.006 dan OR 2.950 artinya pola makan karbohidrat sering memiliki peluang sebanyak 3 kali pada lansia untuk terkena diabetes mellitus dibandingkan dengan pola makan karbohidrat jarang. Sedangkan variabel Aktivitas fisik merupakan variabel confounding karena $p$-value > 0.05 .

\section{Saran}

Berdasarkan hasil penelitian dan pembahasan dapat diberikan saran sebagai berikut:

\section{Bagi Lansia}

Diharapkan lansia melakukan olahraga ringan, mengikuti promosi kesehatan mengenai diabetes mellitus yang diberikan oleh tenaga kesehatan, serta berobat rutin bagi lansia yang sudah terdiagnosa diabetes mellitus guna mengurangi risiko terkena diabetes mellitus.

\section{Posyandu Lansia}

Diharapkan bagi para kader dan tenaga kesehatan yang terlibat dalam posyandu lansia untuk meningkatkan pemberian promosi kesehatan mengenai diabetes mellitus dengan memberikan contoh makanan yang baik untuk dikonsumsi melalui demonstrasi agar dapat mudah dimengerti oleh lansia dan mengurangi angka kejadian diabetes mellitus pada lansia.

\section{Bagi Puskesmas}

Memberikan informasi ataupun penyuluhan-penyuluhan pada posyandu lansia tentang faktor-faktor penyebab terjadinya risiko diabetes mellitus dan melakukan supervisi ke posyandu lansia sebagai upaya untuk pencegahan sejak dini terhadap lansia dengan pola hidup dan gaya hidup yang sehat. Sehingga dapat mengurangi angka kejadian diabetes mellitus terutama pada lansia.

\section{Bagi Peneliti Selanjutnya}

Dari hasil penelitian ini diharapkan dapat digunakan sebagai referensi untuk penelitian selanjutnya terhadap faktor genetik, melakukan pengukuran reduksi urine, pengukuran kadar gula darah pada saat puasa dan gula darah sewaktu menggunakan alat yang baku , 
melakukan penghitungan IMT, serta pada pola makan lansia dengan menambahkan pengkajian ulang pada porsi makan dan asupan gizi responden untuk mendapatkan hasil yang lebih akurat pada penelitian selanjutnya dengan jumlah sampel yang lebih banyak, tempat yang berbeda dan masih berhubungan dengan diabetes mellitus pada lansia. Sehingga dapat meningkatkan status kesehatan pada lansia dan informasi bagi masyarakat luas terhadap pencegahan dini terjadinya risiko diabetes mellitus.

\section{KEPUSTAKAAN}

ACCORD Study Group. (2008). Effects of Intensive Glucose Lowering in Type 2 Diabetes. $N$ Engl $J$ Med. 358:2545-2559. Dalam Buku Pegangan Diabetes Edisi Ke 4. Bilous R, dan Richard D. (2014). Jakarta : Bumi Medika.

Afaf I, Abuelgasim, Maha KM, Osman and Elmahdi B. (2008). Effects of Aloe vera L. (Elsabar) Ethanolic Extract On Blood Glucose Level in Wistar Albino Rats. Khartoum: Journal of Applied Sciences Research University of Khartoum, Faculty of Veterinary Medicine.

Almatsier, S. (2005). Penuntun Diet Edisi Baru, Jakarta, PT Gramedia Pustaka Umum.

American Diabetes Association. (2015). Diagnosis and Classification of Diabetes Mellitus, Diabetes Care,38:8-16.

Ariza, Miguel., (2010). The Economic Consequences of Diabetes and Cardiovaskuler Disease in The United States (Springer 11 : 1-10, 2010).

Aqsha Ramadhanisa, dkk. (2013). Hubungan Antara Aktivitas Fisik
Dengan Kadar HBAlC Pasien Penderita Diabetes Mellitus Tipe 2 Di Laboratorium Patologi Klinik RSUD DR. H. Abdul Moeloek Bandar Lampung. Medical Jurnal Of Lampung University. Vol.2 No. 4. Februari 2013. ISSN 2337-3776.

Arisman. (2004). Gizi Dalam Daur

Kehidupan: Buku Ajar Ilmu Gizi.

Buku Kedokteran EGC: Jakarta.

Arisman.(2011). Obesitas, Diabetes

Melitus \& Dislipidemia. Jakarta:

Penerbit Buku Kedokteran EGC.

Asep Kuswardi, dkk (2008). Pengaruh Relaksasi Terhadap Penurunan Kadar Gula Darah Pada Pasien Diabetes Mellitus 2. Jurnal Keperawatan Indonesia. Vol. 12, No. 2; hal 108-114.

Azwar, Saifuddin. (2006). Penyusunan Skala Psikologis, Yogyakarta: Pustaka Pelajar.

Badan Penelitian Dan Pengembangan Kesehatan Departemen Kesehatan, Republik Indonesia. (2008).

Riset kesehatan dasar : laporan nasional 2007. Jakarta.

Balitbangkes. (2008). Riset Kesehatan Dasar 2007, Laporan Nasional. Jakarta: Balitbangkes Depkes RI.

Balitbang Kemenkes RI. (2013). Riset Kesehatan Dasar; RISKESDAS. Jakarta: Balitbang Kemenkes

RI

Balitbang Kemenkes RI. (2007). Riset Kesehatan Dasar; RISKESDAS. Jakarta: Balitbang Kemenkes RI.

Beckles, Gloria \& Thompson-Reid., Patricia E. (2001). Diabetes \& Women's Health Across the Life Stages : A Public Health Perspective. U.S. Department of Health and Human Services, Centers for Disease Control and Prevention, National Center for Chronic Disease 
Prevention and Health Promotion, Division of Diabetes Translation : Atlanta.

Bharali, R., Tabassum, J., Azad, M. R. H.(2003). Chemomodulatory Effect Of Moringa Oleifera Lam. On Hepatic Carcinogen Metabolizing Enzymes, Antioxidant Parameters, And Skin Papillomagenesis in Mice. Asian Pacific J Cancer Prevent 4. (http://www.apocpcontrol.org/ paper_file/issue_abs /Volume4_No2/Rupjyoti\%20Bharali .pdf).

Bilous R, dan Richard D. (2014). Buku Pegangan Diabetes Edisi Ke 4. Jakarta : Bumi Medika.

Brown, Judith E. et al. (2005). Nutrition Through the Life Cycle. $\left(2^{\text {nd }} e d\right)$. Wadsworth: USA.

Centers for Disease Control and Prevention (CDC),.(2011). TB Elimination Tuberculin Skin Testing, 1-2, http:// http://www.cdc.gov/tb/publications/f actsheets/testing/skintesting.pdf , 17 Oktober 2016.

Chaplin, J.P.(2004). Kamus Lengkap Psikologi. Jakarra: PT. Raja Grafindo Persada.

Corwin, Elizabeth J. (2008). Patofisiologi. Jakarta : Penerbit Buku Kedokteran EGC.

Damayanti, A. (2010). Prevalensi dan Faktor Risiko Kejadian Diabetes Melitus di Daerah Urban Indonesia. Jakarta : Tesis FKMUI.

Davies MJ, Heller S, Skinner T, et al. (2008). Effectiveness of The Diabetes Education and Self Management for Ongoing And Newly Diagnosed (DESMOND) Programme for People With Newly Diagnosed Type 2 Diabetes: Cluster Randomised Controlled Trial. BMJ; 336: $491-495$.
Depkes RI, (2009). Sistem Kesehatan Nasional. Jakarta.

Depkes RI, (2012). Riset Kesehatan Dasar Tahun 2012. Penelitian dan Pengembangan Kesehatan Departemen Kesehatan RI. Badan Litbangkes RI 2012. Diperoleh pada tanggal 25 september 2016

Depkes RI. (2012), Profil Kesehatan Indonesia Tahun 2011. Jakarta : Departemen Kesehatan RI.

Dinkes Jateng. (2011). Profil Kesehatan Jawa Tengah. Semarang : Depkes Jateng.

DKK semarang (2014). Profil Kesehatan Kota Semarang 2013 Semarang; Dinas Kesehatan Kota Semarang.

Eackman, Ari S.

(2011). "Type 1 http://nlm.nih.gov/medlineplus/ency/article /000305.htm. Diakses pada tanggal 7 Oktober 2016.

Effendi, Ferry \& Makhfudli. (2009). Keperawatan Kesehatan Komunitas : Teori dan Praktik dalam

Keperawatan. Jakarta : Salemba Medika.

Garnita, Dita.(2012). "Faktor Risiko Diabetes Melitus di Indonesia (Analisis Data Sakerti 2007)". Depok : Universitas Indonesia.

Gibney, Margareth Kidney, Arab. (2009). Gizi Kesehatan Masyarakat. Jakarta: PT.

Gibson, James,L. (2000). Organisasi, Perilaku, Struktur dan Proses. Edisi ke-5. Cetakan ke-3. Jakarta:

Penerbit Erlangga.

Gill, Geoffrey, Jhon Pickup, dan Gareth Williams. (2001) Difficult Diabetes. London: Blackwell Science Ltd. 
Goldberg, Richard W., dkk. (2007). Quality of Diabetes Care Among Adults With Serious Mentall Illness.

Psychiatric service $58: 536-543$.

Goldstein, Barry J. dan Dirk MuellerWieland. (2008). Type-2 Diabetes: Principles and Practice. New

York: Informa Healthcare. Gramedia Pustaka.

Gumilang, Mega. (2014). Hubungan Aktivitas Fisik Dengan Kadar Gula Darah Pada Pasien Diabetes Melitus Tipe 2 di Rumah Sakit Umum Daerah Karanganyar. Surakarta : Fakultas Kedokteran Universitas Muhammadiyah Surakarta.

Grant, dkk., (2009). Gender-Spesific Epidemiology of Diabetes: A Representative Cross Sectional Study. International Journal for Equity in Health (Online) Vol. 8 No. 6 Hlm 1-12.

Harna. (2007). Psychological Well http//:harnawatiaj.WordPress.Com.Laras Haryono.(2008). Study Deskriptif.

Hiza, H.A., Pratt, C., Mardis, A.L., dan Anand, R., (2000). Body Mass Index and Health, 202, 418-2312.

Himawan,sutisno, wirasmi marwoto.,(2010). Buku Ajar Patologi II edisi ke 1. Jakarta: Sagung seto.

Holy Yunita Nuraini, dkk, (2016). Hubungan Pola Makan, Aktivitas Fisik, Dan Riwayat Keluarga Terhadap DM Tipe 2. Jurnal Ilmu Kesehatan Masyarakat Vol. 05, No. 1. Maret 2016.

International Diabetic Federation, (2015), IDF Diabetes Atlas, http://www.idf.org/atlasmap/atlasma p, 03 Oktober 2016.

Ilyas, E. I., (2011). Olahraga bagi Diabetesi dalam: Soegondo, S., Soewondo, P., Subekti, I., Editor.
Penatalaksanaan Diabetes Melitus Terpadu bagi dokter maupun edukator diabetes. Jakarta: Fakultas Kedokteran Universitas Indonesia.

Irawan, M.Anwari. (2007). Jurnal Glukosa dan Metabolisme Energi. Volume 01(2007) No.06.

Isabella., Dkk. (2014). Hubungan Antara Tingkat Pendidikan Dan Riwayat Keluarga Menderita DM Dengan Kejadian DM Tipe 2 Pada Pasien Rawat Jalan Di Poliklinik Penyakit Dalam BLU Rsup Prof. Dr. R. D. Kandou Manado. Makassar : Fakultas Kesehatan Masyarakat Universitas Sam Ratulangi.

Iswanto. (2004). "Beberapa Faktor Yang Berhubungan Dengan Gula Darah Puasa Pasien Rawat Jalan Diabetes Mellitus Tipe 2 di Puskesmas Kecamatan Pasar Minggu Jakarta Tahun 2004". Skripsi, Fakultas Kesehatan Masyarakat Universitas Being phedonesLambiepok. Dibuka pada website.

Juutilainen A, Lehto S, Ronnemaa T, et al.(2004) Type 2 Diabetes as $A$ "Coronary Heart Disease Equivalent". Diabetes Care. 2005; $28: 2901-2907$.

Katzung, B.G. (2004). Farmakologi Dasar dan Klinik Buku 3 Edisi 8. Penerjemah dan editor: Bagian Farmakologi FK UNAIR. Penerbit Salemba Medika, Surabaya. Hlm $37-41$.

Kementerian Kesehatan RI.,(2010). Rencana Strategis Kementerian Kesehatan Tahun 2010-2014.

Jakarta.

Kemenkes, (2013). Riset Kesehatan Dasar: Riskesdas 2013, Badan Penelitian dan Pengembangan Kesehatan Kementrian Kesehatan RI 2013, Jakarta.

Liang,shi.,et al., (2013). Physical Activity, Smoking, and Alcohol Consumption in Association with Incidence of 
Type 2 Diabetes among MiddleAged and Elderly Chinese Men. Jurnal Vol.8, Issue.11, 2013.

Lindstom J, Ilanne-Parikka P, Peltonen M, et al. (2006). Sustained Reduction In Reduction In The Incidence Of Type 2 Diabetes By Lifestyle Intervention: Follow-Up The Finnish Diabetes Prevention Study. Lancet 2006;368:1673-1679.

Loli dkk, (2012). Hubungan Antara Stress Dengan Dengan Konsep Diri Pada Penderita Diabetes Mellitus Tipe 2. Jurnal Kesehatan Indonesia. Vol. 2, No. 2. Maret 2012.

Lumbantobing. (1997). Kecerdasan pada Usia Lanjut dan Demensia. Jakarta : Balai Penerbit FKUI.

Maryam, R. Siti, dkk. (2008). Mengenal Usia Lanjut dan Perawatannya. Jakarta: Salemba Medika.

Monica L. Meloh, dkk. (2015). Hubungan Kadar Gula Darah Tidak Terkontrol Dan Lama Prevalensi DM Dan Fungsi Kognitif Pada Subyek DM Tipe 2. Journal e-clinic (eCl), Vol. 3 No. 1, Januari - April 2015

Mozzaffarian D, Kamineni A, Carnethen M, et al. (2009). Lifestyle Risk Factors And New-Onset Diabetes Mellitus In Order Adults. Acrh Intern Med. 169: 798-807.

Murti, Bhisma.(2010). Desain dan Ukuran Sampel untuk Penelitian Kuantitatif dan Kualitatif di Bidang Kesehatan edisi ke-2.Yogyakarta: UGM press.

Nathan, David M. dan Linda M.

Delahanty. (2005). Beating

Diabetes: The First Program Clinically

Proven To Dramatically Improve Your Glucose Tolerance. New York: Mc Graw Hill.
Nugroho, Wahyudi.(2000). Keperawatan Gerontik Edisi Kedua. Jakarta: EGC.

Nurlaili Haida K.P., dkk (2013). Hubungan Empat Pilar Pengendalian DM Tipe 2 Dengan Kadar Berata Kadar Gula Darah. Jurnal Bedah Epidemiologi, Vol. 1, No 2. September 2013 : 234-243.

Nurmalina, Rina. (2011). Pencegahan \& Manajemen Obesitas. Bandung :Elex Media Komputindo.

PERKENI. (2006). Konsensus Pencegahan dan Pengelolaan Diabetes Melitus Tipe 2 diIndonesia 2006. Dikutip dari http://www.perkeni.net/index.php?p age=home pada tanggal 20 Desember 2016.

PERKENI.,(2002). Konsensus Pengelolaan Diabetes Mellitus Tipe 2 di Indonesia. Naskah Lengkap Pendidikan Kedokteran Berkelanjutan XVIII Ilmu Penyakit Dalam 2003. Surabaya.

PERKENI., (2011). Konsensus Pengelolaan dan Pencegahan Diabetes Mellitus

Jakarta.

Pipicelli, G. dkk. (2009) "Recommendations For The Nutritional Medical Treatment of Diabetes Mellitus “. Springer 1: 197-201.

Plotnikoff, R. C., (2006). Physical Activity in the Management of based Diabetes: $\quad$ Population-

Perspectives and Strategies. Canadian Journal of Diabetes. 30: 52-62.

Prate, Stefan F. E. dan luc J.C. van Loon. (2009). Exercise Therapy In Type 2 Diabetes. Springer acta diabetol: 263-278. 
Purwanti, O. (2013). Analisis FaktorFaktor Resiko Terjadi Ulkus Kaki Pada Pasien Diabetes Mellitus di Rsud. Dr. Moewardi. Tesis. Depok: Fakultas Ilmu Keperawatan Universitas Indonesia. Diperoleh pada tanggal 3 Oktober 2016

Rahajeng E, Tuminah S. (2009). Prevalensi Hipertensi dan Determinannya di Indonesia. Jakarta: Pusat Penelitian Biomedis dan Farmasi Badan Penelitian Kesehatan Departemen Kesehatan RI.

Rahmawati. (2011). Hubungan Pola Makan Dan Aktivitas Dengan Kadar Gula Darah Penderita Diabetes Melitus Tipe-2 Rawat Jalan Di RSUP Dr. Wahidin Sudirohusodo Makassar. Skripsi : Makassar. Fakultas Ilmu Kesehatan Sam Ratulangi.

Rasmun. (2004). Stres, Koping Dan Adaptasi ( Edisi Pertama ). Jakarta : SAGUNG SETO.

Rochmah W. (2006). Diabetes Melitus Pada Usia Lanjut. Dalam : Aru W, dkk, editors, Ilmu Penyakit Dalam, Jilid III, Edisi keempat, Jakarta : Penerbit FK UI.

Santoso,S dan Ranti, A. Lies. (2004). Kesehatan dan Gizi. Jakarta : Rineka Cipta

Sartika Sumangkut, dkk, (2013). Hubungan Pola Makan Dengan Kejadian Penyakit DM Tipe $2 \mathrm{Di}$ Poli Interne BLU. RSUP. Prof.DR. R.D. Kadao Manado. E-Journal Keperawatan (E-Kp) Vol. 1. No. 1 Agustus 2013.

Schulze MB, Rimm EB, Shai I, Rifai N, $\mathrm{Hu} \quad$ FB.(2004). Relationship Between Adiponectin And Glycemic Control, Blood Lipids, And Inflammatory Markers In Men With
Type 2 Diabetes. Diabetes Care 2004; 27; 1680-1687.

Scholz, B., Gross, R, Schultink. W. and Sastroamidjojo, S. (1997). Anemia Is Associated With Reduced Productivity of Women Workers Even In Less-Physicalystreuous Task British journal of Nutrition. 1997;77: 47-57.

Septian, Adi, Dkk, (2010). Hubungan Antara Tingkat Stres Dengan Kadar Gula Darah Pada Pasien Diabetes Melitus Di Wilayah Kerja Puskesmas Sukoharjo I Kabupaten Sukoharjo. Skripsi : Surakarta. Fakultas Ilmu Kesehatan Universitas Muhammadiyah Surakarta.

Setianto. (2004). Pengaruh Aktifitas Sehari-hari Terhadap Keseimbangan Pada Lansia. Jakarta : Unit Press.

Siagian, Priska. (2012) "Trik Mensiasati Hormone Stress" dalam http://preventionindonesia.com/artic le.php?channel=prevention \&name $=\mathrm{t}$ rik-mensiasati-hormon-stres. Diakses pada tanggal 21 Desember 2016.

Sidartawan S. (2007). Diagnosa dan Klasifikasi Diabetes Melitus Terkini dalam Penatalaksanaan Diabetes Melitus Terpadu.

Smeltzer, \& Bare. (2005). Buku Ajar Keperawatan Medical Bedah Brunner \& Suddart. Edisi 8, Vol 1, alih bahasa: Kuncara Monica Ester. Jakarta: EGC.

Smith, SE dan Read, DJ. (1997). Mycorrhizal symbiosis. Second Edition. Academic Press. Harcourt Brace \& Company Publisher. London. Hlm. 32-79.

Soewondo dkk. (2010). Ketoasidosis Diabetik. Dalam : Aru W, dkk, editors, Ilmu Penyakit Dalam, Jilid 
III, Edisi keempat. Jakarta : Penerbit FK UI.

Soewondo, Pradana. (2006). Koma Hiperosmolar Hiperglikemik Nonketotik. Dalam: Buku Ajar Ilmu Penyakit Dalam. Edisi IV. Jakarta: Fakultas Kedokteran Universitas Indonesia, 1878.

Soeparman. (2001). Ilmu Penyakit Dalam Jilid II. Jakarta : Balai Penerbit FK UI.

Storck, Susan. (2001). http://nlm.nih.gov/medlineplus/ency/article /000896.htm. Diakses pada tanggal 7 Oktober 2016

Sudoyo AW, Setiyohadi B, Alwi I, Simadibrata M, Setiati S. (2009). Buku Ajar Ilmu Penyakit Dalam Jilid edisi $V$. Jakarta: Interna Publishing.

Suhardjo.(1996). Berbagai Cara Pendidikan Gizi. Edisi 1. Cetakan 1. Bumi Aksara. Jakarta.

Suiraoka. (2012). Penyakit Degeneratif. Yogyakarta: Nuhamedika.

Sujaya, I Nyoman. (2009). "Pola Konsumsi Makanan Tradisional Bali Sebagai Faktor Risiko Diabetes Mellitus Tipe 2 di Tabanan". Jurnal Skala Husada Vol.6 No. 1 : 75-81.

Sulistyoningsih, Hariyani. (2011). Gizi Untuk Kesehatan Ibu dan Anak. Yogyakarta: Graha Ilmu.

Supariasa. (2014). Penilaian Status Gizi. Penerbit EGC. Jakarta.

Suyono, Slamet. (2007). Buku Ajar Ilmu Penyakit Dalam Jilid III Edisi 4. Jakarta Departemen Ilmu Penyakit Dalam FKUI.

Teixeira-Lemos, Edite, Sara Nunes, Frederico Teixeira, Flavio Reis. (2011). "Regular Physical Exercise Training Assists in Preventing Type
2 Diabetes Development: Focus on Its Antioxidant And AntiInflammatory Properties". Biomed central cardiovascular diabetology 10: 1-15.

Thomas Aquino E.A (2013). Hubungan Kadar Gula Darah Dengan Tingkat Kognitif Pada Pra Lansia Di Padepokan Denokan Mangunharjo, Depok. Sleman Yogyakarta. Jurnal Keperawatan Respati . Vol. 3 No. 15 Desember 2016. ISSN : 2088- 8872.

TjokCepraxidnoul A.,(2006Diabedesp̉ Sehat dan Bahagia Bersama Diabetes Mellitus. Jakarta: PT Gramedia Pustaka Utama.

Uhthi, Nurul., (2014). Hubungan Aktivitas Fisik Dan Suku Dengan Kejadian Diabetes Mellitus pada Pegawai Universitas Gadjah Mada. Tesis: Universitas Gadjah Mada.

Umpierre et al., (2011). Physical Activity Adviced Only or Structured Exercise Training and Association with HbAlC Levels in Type 2 Diabetes. American Medical Association. 35:107.

United States Departement of Agriculture (USDA), (2007). Nutrient Database for Standard Reference. RI.

Vranic, et al .(2000). 100 Questions and Answer Diabetes, Jakarta: PT. Elex Media Komputindo.

World Health Organization. (2011).

Diabetes. Available

From:

http://www.who.int/mediacentre/fact sheets/fs312/en/index.html.

[Accessed Desember 2016].

Wicaksono, R. P. (2011). Faktorfaktor yang Berhubungan dengan Kejadian Diabetes Melitus.

Semarang: FK UNDIP.

dalam 
Wild S, Roglic G, Green A, et al.(2004). Global Prevalence Of Diabetes: Estimates For The Year 2000

And Projections For 2030. Diabetes Care; 27: 1047-1053.

Wilmore, J. H. and Costill, D. L. (2004). Physiology of Sport and Exercise, Human Kinetics Publishers, United States of America.

Yayuk Farida Baliwati, dkk. (2004).

"Pengantar pangan dan Gizi". Jakarta : Penebar Swadaya.

Yulistina.F. (2016). "Hubungan Asupan Makanan, Stress, Aktivitas Fisik Dengan Hipertensi Pada Wanita Usia Menopause". Tesis. Fakulas Pasca Sarjana Universitas Negeri Semarang.

Yuniatun, Kurniati. (2003). "FaktorFaktor Yang Berhubungan Dengan Pengendalian Kadar Glukosa Darah Puasa Pasien Lama Diabetes Mellitus Lanjut Usia di Poliklinik Diabetes Rumah Sakit Cipto Mangunkusumo." Tesis. Program Studi Ilmu Kesehatan Masyarakat, Program Pasca Sarjana, Universitas Indonesia, Depok.

Zahtamal, dkk (2007). Faktor - faktor Risiko Diabetes Mellitus. Berita kedokteran Masyarakat. Vol.23 No. 3, September 2007 hal 142-147.

Zieve,David. "Hypertention Overview" dalam http://nlm.nih.gov/medlineplus/ency/anato myvideos/000072.htm. Diakses pada tanggal 10 Oktober 2016.

Zurianti S. Manto (2015) Hubungan pola makan dan olahraga dengan kejadian Diabetes Mellitus Tipe 2 di Puskesmas Tilamata Kab. Baelemo. Jurnal keperawatan. Universitas Negeri Gorontalo. 